\title{
PENGEMBANGAN E-MODUL BERBASIS FLIP PDF CORPORATE PADA MATERI LUAS DAN VOLUME BOLA
}

\author{
Erina Dwi Susanti ${ }^{*}$, Ummu Sholihah $^{2}$ \\ 1,2 Tadris Matematika Pascasarjana UIN Sayyid Ali Rahmatullah Tulungagung \\ rinadwi806@gmail.com, sholihah2280@gmail.com
}

Diterima: 08 Juli 2021 Disetujui: 29 Juli 2021 Dipublikasikan: 31 Juli 2021

\begin{abstract}
ABSTRAK
Tujuan dari penelitian ini adalah menghasilkan media pembelajaran yang berupa e-modul berbasis Flip PDF Corporate pada materi luas dan volume bola yang valid, praktis dan efektif. Model pengembangan yang digunakan adalah model penelitian Borg \& Gall, hanya 8 langkah, yaitu: 1) potensi dan masalah, 2) pengumpulan data, 3) desain produk, 4) validasi desain, 5) revisi desain, 6) uji coba produk, 7) revisi produk, 8) uji coba pemakaian. Pada tahap uji coba efektifitas, penelitian ini menggunakan Quasi Experimental Design. Sampel yang digunakan siswa kelas VI SDN 1 Gamping, Tulungagung. Metode pengumpulan data menggunakan angket dan tes. Nilai angket validitas dari ahli media adalah 95,6\% dan ahli materi sebesar 93,4\% termasuk kategori sangat valid. Nilai angket rata-rata kepraktisan pada uji coba pada siswa pada adalah 77,5\% termasuk kategori praktis. Pada uji independent sample t test dari hasil tes diperoleh nilai $\mathrm{t}_{\text {hitung }}$ adalah 5,592 dan $\mathrm{t}_{\text {tabel }}$ adalah 2,080. Karena nilai $\mathrm{t}_{\text {hitung }}>$ $\mathrm{t}_{\text {tabel }}$ maka terdapat perbedaan nilai rata-rata kelas kontrol dan eksperimen dan juga diketahui rata-rata kelas eksperimen yaitu 79,50 lebih tinggi dari nilai rata-rata kelas kontrol yaitu 63,85. Dapat disimpulkan bahwa e-modul berbasis Flip PDF Corporate pada materi luas dan volume bola valid, praktis dan efektif.

Kata kunci: e-modul, Flip PDF Corporate, luas dan volume bola
\end{abstract}

\begin{abstract}
The aim of this research is to create learning media in the form of an e-module based on Flip PDF Corporate on the material surface and the volume of the sphere in a valid, practical and effective way. The development model used is the Borg \& Gall research model, only 8 steps, namely: 1) potential and problems, 2) data collection, 3) product design, 4) design validation, 5) design revision, 6) product test, 7) product revision, 8) trial version use. This study uses a quasi experimental design in the effectiveness phase. The samples used were sixth grade students from SDN 1 Gamping, Tulungagung. Methods of data collection with questionnaires and tests. The value of the validity questionnaire from media experts is $95.6 \%$ and material experts $93.4 \%$, including the very valid category. The average practice value of the questionnaire in the student study was $77.5 \%$ including the practical category. In the t-test of the independent sample, the test results give a $t_{\text {count }}$ value of 5,592 and $t_{\text {table }} 2,080$. Since the value of $t_{\text {count }}>$ $\mathrm{t}_{\text {table }}$ there is a difference in the mean of the control and experimental classes and it is also known that the mean of the experimental class is 79.50 which is higher than the mean of the control class which is 63.85 . It can be concluded that the E-module based on Flip PDF Corporate for the area and volume of the sphere is valid, practical and effective.
\end{abstract}

Keywords: e-module, flip PDF corporate, area and volume of the sphere.

\section{Pendahuluan}

Matematika sebagai suatu ilmu memiliki peran penting dalam dunia pendidikan. Matematika merupakan ilmu dasar yang mendasari munculnya ilmu-ilmu lainn sehingga tidak heran jika matematika muncul dan digunakan dalam ilmu fisika, kimia, astronomi, ekonomi dan ilmu-ilmu lainnya. Proses pengembangan matematika tidak pernah berhenti serta banyak cabang matematika lain yang lahir sebagai tanggapan manusia atas realitas yang terjadi pada kehidupan. Beberapa ahli mendefinisikan mengenai pengertian matematika. Pada dasarnya matematika melatih siswa untuk menggunakan penalarannya 


\section{Range: Jurnal Pendidikan Matematika Vol. 3 No. 1 Tahun 2021 Erina Dwi Susanti, dkk}

supaya berpikir logis dan sistematis dalam menyelesaikan masalah. Karena matematika bersifat khas, maka mempelajarinya memerlukan cara tersendiri (Hudoyo dalam Fahrurrozi \& Hamdi, 2017). Lalu Kline (dalam Fahrurrozi \& Hamdi, 2017) juga menjelaskan bahwa, matematika bukan pengetahuan yang menyendiri, melainkan adanya matematika membantu manusia memahami dan menguasai permasalahan sosial, ekonomi dan lain-lain. Beberapa pengertian, maka penulis menyimpulkan bahwa matematika merupakan ilmu yang kajiannya berupa konsep-konsep abstrak yang ditampilkan dalam angka-angka serta simbol untuk memaknai ide matematis berdasarkan fakta kebenaran.

Matematika yang bersifat abstrak serta kajiannya berupa angka, dan simbol-simbol, menjadikan matematika merupakan salah satu mata pelajaran yang sulit. Oleh karena itu, peran guru sangat diperlukan dalam proses pembelajaran matematika. Menurut Trinova, guru yang dapat menciptakan pembelajaran dapat membuat peserta didik menjadi aktif untuk bertanya., kreatif serta konsentrasi penuh dalam kegiatan pembelajaran (Trinova, 2003). Selain itu, pada era yang modern ini guru juga harus lebih inovatif dengan memanfaatkan perkembangan berbagai teknologi yang ada saat ini.

Penggunaan teknologi dalam pembelajaran matematika akan terasa manfaatnya saat ini. Dalam masa penyebaran COVID-19 saat ini, pemerintah menetapkan kebijakan bahwa pembelajaran di sekolah dialihkan menjadi pembelajaran dengan sistem daring (dalam jaringan). Hal ini sesuai dengan surat edaran nomor 4 Mendikbud tahun 2020 tentang Kebijakan Pendidikan Dalam Masa Darurat Penyebaran COVID -19 bahwa kegiatan belajar dilaksanakan di rumah melalui pembelajaran daring/jarak jauh.

Kurangnya sarana dan prasarana yang menjadi salah satu hambatan dalam kegiatan pembelajaran sehingga hasil belajar tidak bisa seratus persen berjalan lancar atau efektif ( $\mathrm{C}$, Amelia, dkk). Agar pembelajaran selama pandemi bisa efektif, guru harus mengembangkan beberapa kompetensi-kompetensi berikut, seperti kompetensi penguasaan literasi dan IPTEK, kompetensi pengelolaan kelas, kompetensi komunikasi dan sosial (Sudrajat, 2020). Guru juga dituntut untuk menguasai teknologi yang digunakan untuk pembelajaran daring selama masa pandemi.

Salah satu penggunaan teknologi dalam proses pembelajaran adalah dengan memanfaatkan media-media pembelajaran. Media mengacu pada segala sesuatu yang berfungsi menyampaikan informasi, misalnya video, televisi, bahan cetak, komputer dan sebagainya. Media disini berfungsi untuk memfasilitasi berlangsungnya komunikasi (Yaumi, 2018). Media pembelajaran juga diartikan sebagai semua bentuk fisik yang digunakan guru dalam menyajikan materi serta memfasilitasi siswa sehingga sesuai dengan tujuan yang dipelajari. Menurut Briggs, media dipandang sebagai peralatan fisik untuk mengirimkan pesan pada siswa dan mensttimulasi siswa untuk belajar (Yaumi, 2018). Media pembelajaran diartikan sebagai: a. media pembelajaran merupakan wadah dari pesan, b. materi yang ingin disampaikan adalah pesan pembelajaran, c. tujuan yang ingin dicapai adalah proses pembelajaran (Riyana, 2012). Berdasarkan beberapa pendapat dapat disimpulkan bahwa media pembelajaran merupakan segala sesuatu yang digunakan guru untuk menyampaikan pesan atau materi pada siswanya agar mencapai tujuan pembelajaran yang diinginkan.

Media yang digunakan guru harus sesuai dengan tujuan pembelajaran. Media pembelajaran yang tepat digunakan pada masa pandemi ini adalah modul. Modul merupakan program yang disusun dalam bentuk satuan tertentu serta didesain untuk kepentingan belajar siswa, dimana terdapat komponen petunjuk guru, lembar kegiatan siswa, lembar kerja siswa beserta kunci lembar kerja dan lembar tes beserta kuncinya (Riyana, 2012). Menurut Zulhaini, modul adalah bahan ajar yang ditulis pendidik yang memudahkan siswa mempelajari materi secara mandiri (Najuah dkk, 2020). Modul membantu siswa agar dapat belajar secara mandiri serta menjadikan siswa lebih terampil karena menggali informasi atau materi dan mengembangkannya sendiri. Sehingga modul dapat membuat siswa lebih aktif dalam pembelajaran.

Pada era saat ini, modul yang tepat dalam proses pembelajaran adalah modul elektronik atau emodul. E-modul merupakan modul elektronik yang aksesnya dilakukan melalui alat elektronik seperti komputer, handphone, tablet. E-modul dinilai lebih inovatif karena menyajikan materi secara lengkap, apalagi saat ini siswa lebih sering membuka handphone daripada buku. Dengan e-modul siswa bisa menggunakan handphonenya untuk belajar. Kelebihan lain dari e-modul yaitu dapat menyediakan informasi berupa gambar atau bahakan video, sehingga membuat siswa lebih semangat dalam belajar. 


\section{Range: Jurnal Pendidikan Matematika Vol. 3 No. 1 Tahun 2021 Erina Dwi Susanti, dkk}

Berikut beberapa kelebihan e-modul dibandingkan modul konvensional antara lain: a) e-modul dinilai lebih menarik karena dilengkapi gambar, video dan sebagainya, b) lebih interaktif karena siswa dapat melakukan evaluasi secara mandiri, c) bebas kertas karena bentuknya elektronik, d) multiplatform karena dapat digunakan melalui komputer, laptop dan handphone (Partono, 2019).

Salah satu kelebihan e-modul yang telah dijelaskan sebelumnya adalah e-modul dinilai menarik karena dilengkapi gambar. Apalagi jika materi yang dipelajari adalah materi geometri. Pada tingkat sekolah dasar, materi geometri yang diajarkan diantaranya mengenai beberapa bangun datar dan bangun ruang. Pada kelas VI semester dua salah satu materi geometri yang diajarkan adalah materi bangun ruang. Berdasarkan salinan Peraturan Menteri Pendidikan dan Kebudayaan RI Nomor 37 Tahun 2018 tentang Perubahan Atas Peraturan Menteri Pendidikan dan Kebudayaan Nomor 24 Tahun 2006 Tentang Kompetensi Inti dan Kompetensi Dasar Pelajaran Pada Kurikulum 2013 Pada Pendidikan Dasar dan Pendidikan Menengah disebutkan bahwa pada jenjang kelas VI Sekolah Dasar, pada KD 3.6 siswa membandingkan prisma, tabung, limas, kerucut dan bola. Sedangkan pada KD 4.6 siswa mengidentifikasi prisma, tabung, limas, kerucut dan bola (Kementrian Pendidikan dan Kebudayaan RI, 2018). Salah satu materi yang digunakan dalam penelitian pengembangan ini adalah mengenai bangun ruang bola. Pada materi mengenai bangun ruang bola, akan dijelaskan mengenai definisi dari bangun ruang bola, sifat-sifat bola serta rumus-rumus untuk mencari luas permukaan dan volume bola.

Berdasarkan observasi pada siswa kelas VI di suatu sekolah dasar di Tulungagung, dalam kegiatan belajar mengajar lewat daring, tugas-tugas lebih banyak diberikan melalui whatsapp. Melalui whatsapp guru sering mengirimkan video-video pembelajaran mengenai materi yang diajarkan sehingga siswa lebih fokus bekajar melalui handphone daripada membaca buku-buku pelajaran yang dipinjamkan sekolah. Siswa juga lebih banyak membaca materi-materi pembelajaran melalui internet di handphone. Berdasarkan temuan tersebut, peneliti mengembangkan modul yang dapat dibaca atau dibuka melalui handphone Jika modul pada umumnya berbentuk kertas, namun e-modul ini dalam pembuatannya memerlukan aplikasi. Salah satu aplikasi yang bisa digunakan yaitu aplikasi Flip PDF Corporate. Flip $P D F$ Corporate merupakan sebuah software yang bisa digunakan untuk membuka halaman sebuah modul layaknya buku. Dengan menggunakan Flip PDF Corporate siswa akan lebih tertarik untuk belajar karena tampilan dari Flip PDF Corporate ini menarik. Hal tersebut sesuai dengan penelitian Hanifa Ainun Nisa, dkk, yang menyimpulkan bahwa hasil uji kemenarikan pembelajaran menggunakan e-modul berbasis Flip PDF Professional termasuk kategori menarik dan efektif apabila diterapkan untuk siswa SMP kelas VII (Nisa, dkk, 2020). Penelitian lain juga dilakukan oleh Andi Dian Angriani, dkk. Hasil penelitian menyimpulkan bahwa pengembangan media pembelajaran digital book dengan menggunakan aplikasi Flip PDF dapat meningkatkan pemahaman teori dan minat peserta didik khususnya pada materi aljabar jenjang SMP (Angriani, dkk 2020). Berdasarkan hasil penelitian kepustakaan E. Watin dan R. Kustijono, penggunaan e-modul dengan Flip PDF Professional efektif dalam melatih keterampilan sains dan memiliki peluang untuk dikembangkan agar menjadi media pembelajaran yang baik (Watin \& Kustijono, 2017). Berdasarkan uraian di atas maka perlu dilakukan penelitian untuk mengembangkan sebuah media yang dapat digunakan dalam proses pembelajaran yang valid, praktis dan efektif materi bangun ruang bola.

\section{Metode Penelitian}

Metode dalam penelitian ini adalah penelitian pengembangan atau Research and Development. Metode penelitian pengembangan adalah metode penelitian yang digunakan untuk menghasilkan suatu produk, serta menguji bagaimana keefektifan suatu produk tersebut (Sugiyono, 2015). Model penelitian pengembangan menggunakan model Borg \& Gall dalam Sugiyono (2015), namun hanya 8 langkah yaitu: 1) Potensi dan masalah, 2) pengumpulan data, 3) desain produk, 4) validasi desain, 5) revisi desain, 6) ujicoba produk, 7) revisi produk, 8) uji coba pemakaian. Penelitian ini lebih menitikberatkan pada tahap ujicoba produk seperti Uji kepratisan dan uji efektifitas. 


\section{Range: Jurnal Pendidikan Matematika Vol. 3 No. 1 Tahun 2021 Erina Dwi Susanti, dkk}

Pada tahap uji coba efektifitas produk, penelitian ini menggunakan Quasi Experimental Design. Sample yang digunakan yaitu dua kelas VI SDN I Gamping, Tulungagung dimana kelas pertama sebagai kelompok eksperiman dan kelas kedua sebagai kelompok kontrol. Siswa pada kelas eksperimen berjumlah 10 siswa sedangkan pada kelas kontrol berjumlah 13 siswa. Penelitian dilaksanakan pada semester 2 tahun ajaran 2020/2021 mulai bulan April hingga Juni.

Metode pengumpulan data yang digunakan yaitu angket dan tes. Angket diberikan pada dua ahli yaitu ahli media dan materi untuk menilai kevalidan media yang dikembangkan yaitu berupa e-modul berbasis Flip PDF Corporate. Angket respon siswa untuk mengukur kepraktisan media yang dikembangkan peneliti. Angket respon disusun dalam google form dan diberikan pada siswa untuk mengetahui media yang dikembangkan praktis atau tidak. Adapun instrumen selain angket adalah tes. Tes berupa soal pilihan ganda mengenai materi luas dan volume bola setelah siswa mengikuti pembelajaran pada kelas eksperimen maupun kontrol. Pada penelitian pengembangan ini teknik analisis data menggunakan statistik deskriptif.

Pada angket validasi ahli media, terdapat beberapa aspek yang dinilai dalam e-modul berbasis Flip PDF Corporate yang dikembangkan peneliti, antara lain aspek fisik/tampilan, pendahuluan, pemanfaatan, tugas/evaluasi serta rangkuman. Masing-masing aspek memiliki beberapa kriteria atau indikator (Sungkono, 2012). Pada angket validasi ahli materi, terdapat beberapa aspek yang dinilai dalam e-modul berbasis Flip PDF Corporate yang dikembangkan peneliti, antara lain aspek pendahuluan, pembelajaran, isi, tugas/evaluasi, rangkuman. Masing-masing aspek juga memiliki beberapa kriteria atau indikator (Sungkono, 2012). Angket validasi menggunakan skala likert dengan lima pilihan skor penilaian yaitu 1. Sangat tidak setuju, 2. Tidak setuju, 3. Ragu-ragu, 4. Setuju 5. Sangat setuju (Sugiyono, 2015) . Masing-masing skor dihitung dengan rumus. Rumus yang digunakan untuk menghitung data hasil uji validasi ahli media dan materi adalah teknik analisis presentase (Arikunto, 2010).

$$
\text { Nilai }=\frac{\text { jumlah skor yang diperoleh }}{\text { jumlah skor maksimal }} \times 100 \%
$$

Tabel 1. Kriteria Hasil Validasi

\begin{tabular}{cc}
\hline Skor dalam presentase & Kriteria validasi \\
\hline $81 \%-100 \%$ & Sangat Layak \\
$61 \%-80 \%$ & Layak \\
$41 \%-60 \%$ & Cukup Layak \\
$21 \%-40 \%$ & Kurang Layak \\
$<20 \%$ & Tidak Layak \\
\hline
\end{tabular}

Angket respon siswa digunakan untuk mengukur kepraktisan media yang dikembangkan peneliti. Angket respon berisi 16 butir pernyataan mengenai e-modul berbasis Flip PDF Corporate yang dikembangan peneliti, yang disusun melalui google form dengan menggunakan skala likert. Siswa dengan mengisi angket resepon dengan lima pilihan skor penilaian yaitu 1. Sangat tidak setuju, 2. Tidak setuju, 3 . Ragu-ragu, 4. Setuju 5. Sangat setuju (Sugiyono, 2015). Skor yang diperoleh dari jawaban siswa kemudian diubah ke dalam bentuk presentase (Arikunto, 2010)

Nilai praktikalitas $=\frac{\text { jumlah skor yang diperoleh }}{\text { jumlah skor maksimal }} \times 100 \%$ 
Range: Jurnal Pendidikan Matematika Vol. 3 No. 1 Tahun 2021 Erina Dwi Susanti, dkk

Tabel 2. Kriteria Nilai Praktikalitas

\begin{tabular}{cc}
\hline Presentase & Kriteria \\
\hline $81 \%-100 \%$ & Sangat Praktis \\
$61 \%-80 \%$ & Praktis \\
$41 \%-60 \%$ & Cukup Praktis \\
$21 \%-40 \%$ & Kurang Praktis \\
$<20 \%$ & Tidak Praktis \\
\hline
\end{tabular}

Pada akhir kegiatan pembelajaran, siswa pada kelas kontrol dan eksperimen diberi soal posttest mengenai luas dan volume bola. Hasil skor posttest siswa diuji dengan statistik deskriptif menggunakan independent sample $t$ test untuk mengetahui adakah perbedaan rata-rata antara dua kelompok bebas atau tidak berpasangan (Statistic Center Undip, 2016). Dalam penelitian ini independent sample $t$ test digunakan untuk mengetahui apakah ada perbedaan nilai rata-rata kelas eksperimen dan kontrol, dimana kelas eksperimen adalah kelas dengan pembelajaran menggunakan e-modul berbasis Flip PDF Corporate sedangkan kelas kontrol adalah kelas dengan pembelajaran konvensional (tanpa menggunakan e-modul). Uji independent sample t test menggunakan aplikasi SPSS 16.0. Lalu nilai t hitung dibandingkan dengan $\mathrm{t}$ tabel. Jika nilai t hitung lebih besar dari t tabel, berarti terdapat perbedaan antara kelas eksperimen dan kontrol. Apabila nilai rata-rata kelas eksperimen lebih tinggi dari kelas kontrol, e-modul berbasis Flip $P D F$ Corporate yang dikembangkan peneliti efektif digunakan.

\section{Hasil Penelitian dan Pembahasan}

Penelitian ini menghasilkan sebuah produk berupa e-modul berbasis berbasis Flip PDF Corporate pada materi luas dan volume bola. Pada tahap pertama peneliti menganalisis kebutuhan siswa, ternyata belum ada sumber belajar yang praktis dan efektif, juga ditemukan beberapa masalah atau potensi ketika siswa kelas VI saat pembelajaran daring berlangsung. Siswa diberikan tugas oleh gurunya melalui handphone. Pada saat pelajaran matematika, siswa diberi berbagai video pembelajaran melalui Youtube, untuk memudahkan siswa mengerjakan soal-soal yang diberikan guru. Namun dengan adanya pembelajaran online siswa lebih fokus untuk belajar melaui handphonenya masing-masing, sehingga siswa sering mengabaikan buku-buku paket yang dipinjamkan sekolah. Dampak pandemi pada sektor pendidikan lainnya yaitu, rendahnya minat baca siswa ( Kasiyun, 2015). Oleh karena minat baca yang rendah, siswa mengalami kesuliatan memahami tugas-tugas yang diberikan guru, terutama konsep matematika. Dengan adanya masalah serta potensi tersebut peneliti mengembangakan sebuah e-modul berbasis Flip PDF Corporate pada materi luas dan volume bola. E-modul ini bisa diakses melalui handphone, sehingga memudahkan siswa belajar saat pembelajaran daring saat ini.

Tahap selanjutnya yaitu peneliti mengumpulkan data. Data yang dikumpulkan berupa beberapa buku ajar matematika kelas VI Sekolah Dasar serta data mengenai KI dan KD matematika kelas VI. Data tersebut nantinya digunakan untuk menyusun sebuah e-modul berbasis berbasis Flip PDF Corporate. Setelah itu peneliti mulai mendesain produk dengan memperhatikan KI serta KD mengenai materi luas dan volume bola. setelah berbasis Flip PDF Corporate jadi, maka tahap selanjutnya adalah validasi desain. 


\section{Range: Jurnal Pendidikan Matematika Vol. 3 No. 1 Tahun 2021 Erina Dwi Susanti, dkk}

Berikut sebagian tampilan e modul berbasis berbasis Flip PDF Corporate yang dikembangkan.

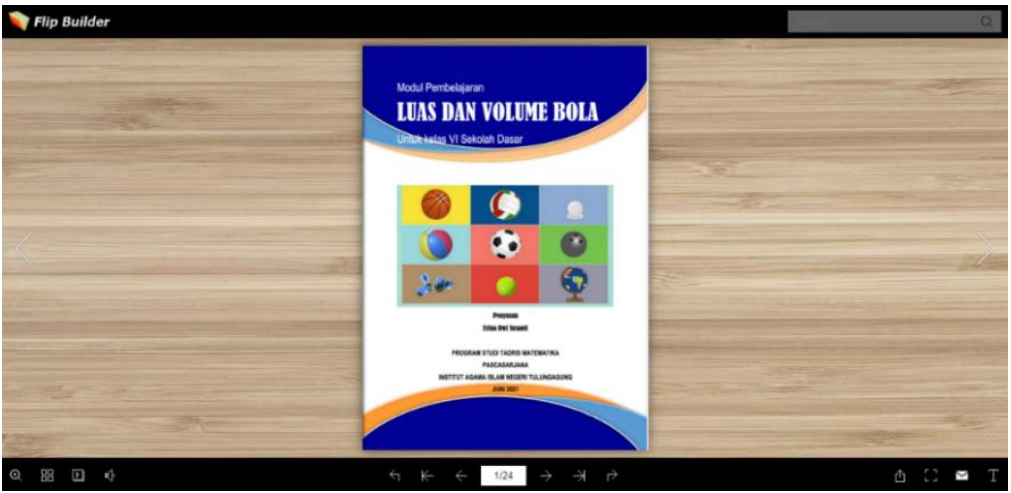

Gambar 1. Tampilan cover e-modul

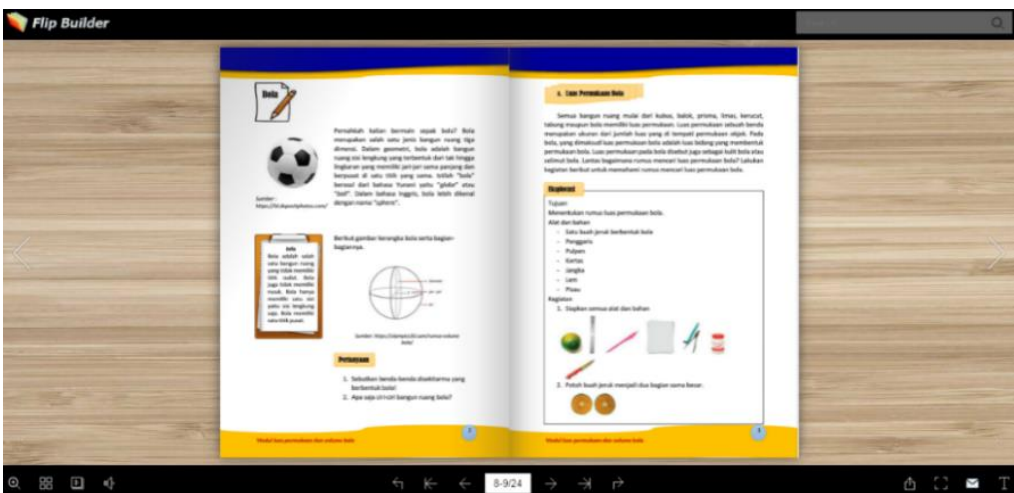

Gambar 2. Tampilan Sebagian Materi

Desain e-modul di validasi oleh ahli media serta ahli materi. Ahli media adalah seorang dosen yang ahli media pembelajaran dan ahli materinya adalah guru kelas VI Sekolah Dasar di Tulungagung. Berikut tabel mengenai hasil validasi ahli media dan ahli materi.

Tabel 3. Hasil Validasi Ahli Media

\begin{tabular}{cccc}
\hline No & Aspek & Nilai & Kriteria Validasi \\
\hline 1. & Fisik/tampilan & $100 \%$ & Sangat Valid \\
2. & Pendahuluan & $86 \%$ & Sangat Valid \\
3. & Pemanfaatan & $97 \%$ & Sangat Valid \\
4. & Tugas/evaluasi & $100 \%$ & Sangat Valid \\
5. & Rangkuman & $95 \%$ & Sangat Valid \\
& Rata-rata & $95,6 \%$ & Sangat Valid \\
\hline
\end{tabular}

Berdasarkan hasil validasi ahli media, aspek fisik/tampilan mendapat nilai 100\% dengan kriteria sangat valid. Aspek pendahuluan mendapat nilai $86 \%$ dengan kriteria sangat valid. Aspek pemanfaatan mendapat kriteria 97\% dengan kriteria sangat valid. Aspek tugas/evaluasi mendapat nilai 100\% dengan kriterian sangat valid. Aspek rangkuman mendapat nilai 95\% dengan kriteria sangat valid sehingga ratarata nilai validasi ahli media adalah $95,5 \%$ dengan kriteria sangat valid. 


\section{Range: Jurnal Pendidikan Matematika Vol. 3 No. 1 Tahun 2021 Erina Dwi Susanti, dkk}

Tabel 4. Hasil Validasi Ahli Materi

\begin{tabular}{cccc}
\hline No & Aspek & Nilai & Kriteria Validasi \\
\hline 1. & Pendahuluan & $86 \%$ & Sangat Valid \\
2. & Pembelajaran & $100 \%$ & Sangat Valid \\
3. & Isi & $96 \%$ & Sangat Valid \\
4. & Tugas/evaluasi & $90 \%$ & Sangat Valid \\
5. & Rangkuman & $95 \%$ & Sangat Valid \\
& Rata-rata & $93,4 \%$ & Sangat Valid \\
\hline
\end{tabular}

Berdasarkan hasil validasi ahli materi, aspek pendahuluan mendapat nilai $86 \%$ dengan kriteria sangat valid. Aspek pembelajaran mendapat nilai $100 \%$ dengan kriteria sangat valid. Aspek isi mendapat kriteria 96\% dengan kriteria sangat valid. Aspek tugas/evaluasi mendapat nilai 90\% dengan kriteria sangat valid. Aspek rangkuman mendapat nilai 95\% dengan kriteria sangat valid. Sehingga rata-rata nilai validasi ahli media adalah 93,4\% dengan kriteria sangat valid.

Tabel 5. Rata-rata Hasil Validasi Ahli Media dan Materi

\begin{tabular}{cccc}
\hline No & Ahli & Nilai & Kriteria validasi \\
\hline 1. & Ahli Media & $95,5 \%$ & Sangat Valid \\
2. & Ahli Materi & $93,4 \%$ & Sangat Valid \\
& Rata-rata & $94,45 \%$ & Sangat Valid \\
\hline
\end{tabular}

Berdasarkan rata-rata ahli media dan ahli materi diperoleh nilai 94,45\% dengan kriteria sangat valid. Berdasarkan hasil validasi ahli media dan ahli materi dapat disimpulkan bahwa e-modul berbasis Flip PDF Corporate termasuk kriteria sangat valid. Pada ahli media, masing-masing aspek fisik, pendahuluan, pemanfaatan, tugas serta evaluasi memenuhi kriteria sangat valid. Karena e-modul valid, maka e-modul layak untuk digunakan atau diuji cobakan pada siswa. Hal ini sejalan dengan pendapat Arikunto, yang menyatakan bahwa suatu instrumen yang valid atau sahih mempunyai validitas tinggi. Sebaliknya, instrumen yang kurang valid berarti memiliki validitas rendah (Arikunto, 2010). Selain itu, bahan ajar dikatakan valid jika bahan ajar tersebut dapat menunjukkan suatu kondisi yang sudah sesuai dengan isi dan konstruknya (Arikunto, 2008). Hal ini terlihat dari masing-masing aspek yang dinilai mendapat kriteria sangat valid dari ahli media maupun materi. Jika e-modul berbasis Flip PDF Corporate valid, nantinya dapat mengukur apa yang seharusnya diukur dalam kegiatan pembelajaran nantinya. Sesuai dengan pendapat Latishma, bahwa e-modul dapat dikatakan valid apabila e-modul tersebut secara tepat, shahih, dapat mengukur apa yang seharusnya diukur (Latisma, 2011). Walaupun demikian ada beberapa revisi dari ahli media serta ahli materi sehingga, e-modul mengalami revisi. Beberapa revisi teknis seperti keterbacaan dan pengetikan, Ahli media menyarankan agar beberapa soal-soal di e-modul dirubah, karena terlalu sulit bagi siswa SD kelas VI. Sedangkan pada ahli materi menyarankan agar pada bagian tujuan pembelajaran seharusnya memuat A, B, C, D (Audience, Behavior, Condition serta Degree). Setelah menerima saran perbaikan dari dua ahli media dan materi, peneliti melakukan revisi desain.

Setelah desain selesai revisi, tahap selanjutnya yaitu uji coba kelompok kecil. Peneliti memilih 5 siswa sebagai kelompok kecil. Pada kelompok kecil siswa diberi angket respon siswa mengukur kepraktisan e-modul berbasis Flip PDF Corporate yang dikembangkan peneliti. 


\section{Range: Jurnal Pendidikan Matematika Vol. 3 No. 1 Tahun 2021 Erina Dwi Susanti, dkk}

Tabel 6. Hasil Angket Respon Siswa

\begin{tabular}{cccc}
\hline No & Siswa & Presentase Kepraktisan & Kriteria \\
\hline 1. & Siswa 1 & $75 \%$ & Praktis \\
2. & Siswa 2 & $87,5 \%$ & Sangat Praktis \\
3. & Siswa 3 & $80 \%$ & Praktis \\
4. & Siswa 4 & $83,75 \%$ & Sangat Praktis \\
5. & Siswa 5 & $61,25 \%$ & Praktis \\
& Rata-rata & $77,5 \%$ & Praktis \\
\hline
\end{tabular}

Berdasarkan uji coba kelompok kecil, siswa pertama menilai kepraktisan sebesar $75 \%$, termasuk kriteria praktis. Pada siswa kedua kepraktisan sebesar $87,5 \%$ termasuk kriteria sangat praktis. Siswa ketiga menilai kepraktisan sebesar $80 \%$, termasuk kriteria praktis. Pada siswa keempat, kepraktisan sebesar $83,75 \%$, termasuk kriteria praktis. Pada siswa kelima kepraktisan sebesar $61,25 \%$, termasuk kriteria praktis sehingga rata-rata kepraktisan diperoleh sebesar 77,5\%, termasuk kriteria praktis. Menurut Rochmad, bahan ajar yang dikembangkan dikatakan praktis jika para ahli dan praktisi menyatakan bahwa secara teoretis bahan ajar dapat diterapkan dan tingkat keterlaksanaannya termasuk dalam kategori baik (Rochmad, 2012). Berdasarkan angket respon siswa, e-modul berbasis Flip PDF Corporate termasuk kriteria praktis. Sehingga dapat dikatakan bahwa e-modul Flip PDF Corporate termasuk dalam kategori baik. Hal ini sesuai dengan penelitian Andi Dian Anggriani, dkk yang menyatakan bahwa media pembelajaran digital book dengan menggunakan app flip $p d f$ sangat praktis karena dapat meningkatan pemahaman teori dan minat pada peserta didik (Angriani, 2020). Selain dapat meningkatkan pemahaman siswa, Flip PDF Corporate termasuk kriteria praktis dalam segi kemudahan dalam menyimpannya, karena dapat dibaca melalui handphone siswa masing-masing. Hal ini sesuai dengan pendapat Arikunto, bahwa kepraktisan merupakan suatu kemudahan yang ada pada suatu instrumen evaluasi baik dalam mempersiapkan, menggunakan, menginterpretasi memperoleh hasil maupun kemudahan dalam menyimpannya (Arikunto, 2008). Dengan demikian maka e-modul Flip PDF Corporate pada materi luas dan volume bola praktis apabila diterapkan dalam kegiatan pembelajaran.

Setelah merevisi e-modul berbasis Flip PDF Corporate, peneliti melakukan uji coba pemakaian pada kelompok besar. Tahap uji coba pemakaian e-modul untuk mengetahui keefektifan e-modul yang dikembangkan peneliti. Siswa kelas VI A dipilih sebagai kelas eksperimen sehingga proses pembelajaran menggunakan e-modul berbasis berbasis Flip PDF Corporate. Sedangkan kelas B dipilih sebagai kelas kontrol, sehingga pembelajaran menggunakan metode konvensional. Setelah kegiatan pembelajaran selesai, kedua kelas eksperimen dan kontrol diberi post tes untuk melihat perbedaan nilai rata-rata kelas eksperimen dan kontrol. Uji statistika yang digunakan adalah independent sample t test. Berikut langkahlangkah ujinya.

1. Sebelum melakukan uji independent sample $t$ test, peneliti melakukan uji prasyarat yaitu uji normalitas dan homogenitas dengan SPSS. Karena sample data kurang dari 50 maka menggunakan Uji Shapiro-Wilk (Raharjo, 2015). Jika, nilai p-value (Sig.) > 0.05, maka data berdistribusi normal. Berdasarkan hasil output SPSS, nilai Sig. kelas eksperimen sebesar 0,152 dan nilai Sig. kelas kontrol sebesar 0,589 dimana nilai $p$-value (Sig.) keduanya lebih dari 0,05, sehingga data nilai post test kelas eksperimen dan kelas kontrol berdistribusi normal.

2. Setelah data normal, langkah selanjutnya adalah uji homogenitas. Jika, nilai p-value (Sig.) $>0.05$, maka varians data homogen. Berdasarkan hasil output SPSS, nilai p-value (Sig.) adalah 0,169, dimana nilainya lebih dari 0,05 . Sehingga varians data tersebut homogen.

3. Setelah data normal dan homogen, maka langkah selanjutnya, uji data dengan independent sample $t$ test. Berdasarkan hasil output, diperoleh nilai t hitung adalah 5,592. Jika $\mathrm{df}=21 \mathrm{dan} \alpha=0,05$ maka nilai $t$ tabel adalah 2,080. Oleh karena nilai thitung $>\mathrm{t}$ tabel, maka tolak $\mathrm{H}_{0}$, terima $\mathrm{H}_{1}$ sehingga dapat 


\section{Range: Jurnal Pendidikan Matematika Vol. 3 No. 1 Tahun 2021 Erina Dwi Susanti, dkk}

disimpulkan bahwa terdapat perbedaan nilai rata-rata kelas eksperimen dan kontrol. Nilai rata-rata kelas kelas eksperimen adalah 79,50 sedangkan nilai rata-rata kelas kontrol adalah 63,85.

Berdasarkan rata-rata, nilai kelas eksperimen lebih baik daripada kelas kontrol, sehingga dapat disimpulkan bahwa penggunaan e-modul berbasis Flip PDF Corporate pada materi luas dan volume bola pada kelas eksperimen efektif. Sesuai dengan pendapat Mulyasa, yang menyatakan bahwa modul sebagai paket beajar yang mandiri dirancang secara sitematis untuk membantu peserta didik mencapai tujuan belajar (Mulyasa, 2005). Oleh karena terdapat perbedaan nilai antara kelas kontrol, maka Flip PDF Corporate pada materi luas dan volume bola dapat meningkatkan hasil belajar matematika, sesuai dengan penelitian Srihono dan Fuad yang menyimpulkan bahwa Flip book plus dapat meningkatkan hasil belajar matematika (Srihono \& Haninul Fuad, 2018). Berdasarkan penelitian Hanifa Ainun Nisa, dkk., e-modul dengan Flip PDF Professional berbasis gamifikasi efektif dan layak untuk bahan ajar matematika (Nisa et al., 2020). Dengan demikian maka e-modul Flip PDF Corporate pada materi luas dan volume bola efektif apabila diterapkan dalam kegiatan pembelajaran.

\section{Kesimpulan \\ Simpulan}

Berdasarkan hasil penelitian dapat disimpulkan bahwa e-modul berbasis Flip PDF Corporate pada materi luas dan volume bola yang dikembangkan peneliti dengan model penelitian Borg \& Gall yang terdiri dari delapan langkah, yaitu: 1) Potensi dan masalah, 2) pengumpulan data, 3) desain produk, 4) validasi desain, 5) revisi desain, 6) uji coba produk, 7) revisi produk, 8) uji coba pemakaian, termasuk kriteria valid, praktis dan efektif. Nilai angket validitas dari ahli media adalah 95,6\% termasuk kategori sangat valid. Sedangkan nilai angket validitas dari ahli materi adalah 93,4\% termasuk kategori sangat valid. Nilai rata-rata kedua ahli adalah $94,45 \%$ termasuk kategori sangat valid. Nilai angket rata-rata kepraktisan pada uji coba siswa pada kelompok kecil adalah 77,5 \% termasuk kategori praktis. Pada uji independent sample $t$ test diperoleh nilai $t_{\text {hitung }}$ adalah 5,592 dan $t_{\text {tabel }}$ adalah 2,080. Karena nilai $t_{\text {hitung }}>$ $t_{\text {tabel }}$ disimpulkan bahwa terdapat perbedaan nilai rata-rata kelas eksperimen dan kontrol. Selain itu nilai rata-rata kelas eksperimen yaitu 79,50 lebih tinggi dari nilai rata-rata kelas kontrol yaitu 63,85. Dapat disimpulkan bahwa e-modul berbasis Flip PDF Corporate pada materi luas dan volume bola valid, praktis dan efektif.

Saran

Saran dari peneliti yaitu, siswa masih kesulitan dalam menyelesaikan soal matematika, terutama mengenai materi volume dan luas permukaan suatu bangun ruang. Oleh karena itu perlu dikembangkan media pembelajaran seperti e-modul berbasis Flip PDF yang menarik dan praktis agar siswa semangat dalam belajar.

\section{Daftar Pustaka}

Angriani, D. (2020). Pengembangan Media Pembelajaran Digital Book pada Materi Aljabar. Delta-Pi: Jurnal Matematika Dan Pendidikan Matematika, 9(2), 13-30.

Arikunto, S. (2008). Dasar-Dasar Evaluasi Pendidikan. Jakarta: Bumi Aksara.

Arikunto, S. (2010). Prosedur Penelitian Suatu Pendekatan Praktik. Jakarta: Rineka Cipta.

C, B. D., Amelia, A., Hasanah, U., Putra, A. M., \& Rahman, H. (n.d.). Kompetensi Guru di Masa Pandemi COVID -19. Jurnal Pendidikan Guru Sekolah Dasar, 28-37.

Fahrurrozi, \& Hamdi, S. (2017). Metode Pembelajaran Matematika. (D. S. M. Ibrahim, Ed.). Selong.

Kasiyun, S. (2015). Upaya Meningkatkan Minat Baca Sebagai Sarana Untuk Mencerdaskan Bangsa. Jurnal Pena Indonesia, 1(1), 79-95.

Kementrian Pendidikan dan Kebudayaan RI. Peraturan Menteri Pendidikan Dan Kebudayaan Republik Indonesia Nomor 37 Tahun 2018 Tentang Perubahan Atas Peraturan Menteri Pendidikan Dan Kebudayaan Nomor 24 Tahun 2016 Tentang Kompetensi Inti Dan Kompetensi Dasar Pelajaran Pada Kurikulum 2013 Pada Pendi (2018). Retrieved from jdih.kemdikbud.go.id 


\section{Range: Jurnal Pendidikan Matematika Vol. 3 No. 1 Tahun 2021 Erina Dwi Susanti, dkk}

Latisma. (2011). Evaluasi Pembelajaran. Padang: UNP Press.

Mulyasa. (2005). Implementasi Kurikulum 2004 Panduan Pembelajaran KBK. Bandung: Remaja Rosdakarya.

Najuah, Lukitoyo, P. S., \& Wirianti, W. (2020). Modul Elektronik Prosedur Penyusunan dan Aplikasinya. Yayasan Kita Menulis.

Nisa, H. A., Wahyu, R., \& Putra, Y. (2020). Efektivitas E-Modul dengan Flip Pdf Professional Berbasis Gamifikasi Terhadap Siswa SMP. Jurnal Pendidikan Matematika Raflesia, 5(2), 13-25.

Partono. (2019). Pemanfaatan Modul Dalam Pembelajaran. Retrieved from https://sma1pegandon.sch.id/read/107/pemanfaatan-emodul-dalam-pembelajaran

Raharjo, S. (2015). Cara Uji Normalitas Shapiro-Wilk dengan SPSS Lengkap. Retrieved from https://www.spssindonesia.com/2015/05/cara-uji-normalitas-shapiro-wilk-dengan.html?m=1

Riyana, C. (2012). Media Pembelajaran. Jakarta. Retrieved from Dirjen Pendidikan Islam Keentrian Agama Republik Indonesia

Rochmad. (2012). Desain Model Pengembangan Perangkat Pembelajaran Matematika. Jurnal Kreano, 3.

Srihono, \& Haninul Fuad, M. (2018). Pengaruh Media Flip Book Plus Terhadap Hasil Belajar Matematika Siswa Kelas X-IIS SMAN 1 Mejobo Materi Trigonometri Tahun Pelajaran 2018/2019. Jurnal Pendidikan Matematika, 1(1).

Statistic Center Undip. (2016). Independent Sample $\mathrm{T}$ Test. Retrieved from http://scundip.org/uncategorized/independent-sample-t-test/

Sudrajat, J. (2020). Kompetensi Guru di Masa Pandemi COVID -19. Jurnal Riset Ekonomi Dan Bisnis, $13(1), 100-110$.

Sugiyono. (2015). Metode Penelitian Pendidikan. Bandung: Alfabeta.

Sungkono. (2012). Pengembangan Instrumen Evaluasi Media Modul Pembelajaran. Majalah Ilmiah Pembelajaran, (2), 1-16.

Trinova, Z. (2003). Hakikat belajar dan bermain menyenangkan bagi peserta didik. Jurnal Al-Ta'lim, Jilid $1,209-215$.

Watin, E., \& Kustijono, R. (2017). Efektivitas penggunaan E-book dengan Flip PDF Professional untuk melatihkan keterampilan proses sains. In Seminar Nasional Fisika (SNF) (pp. 124-129).

Yaumi, M. (2018). Media dan Teknologi Pembelajaran. (S. F. S. Sirate, Ed.) (Pertama). Jakarta: KENCANA 